\title{
A definição da vocação poética goethiana nos livros 13 a 16 de Dichtung und Wahrheit (uma investigação)
}

\author{
[The establishment of the Goethian poetic vocation in books \\ 13 to 16 of Dichtung und Wahrheit (an investigation)] \\ http://dx.doi.ors/10.11606/1982-88372236223
}

Marco Antônio Araújo Clímaco ${ }^{1}$

\begin{abstract}
Designed do fill in the gaps of an existence that became widely known with the publication of Werther, the autobiographical account of Dichtung und Wahrheit will devote much of the last seven books to the narration of circumstances that would have enabled Goethe to find a field of work compatible with the strident repercussion of Werther, but at the same time consistent with a poetic vocation to which Goethe refuses any direct and 'didactic' interference in human affairs, since he begins to conceive it 'entirely as nature'. The article intends to review this decisive moment in the construction of the Goethean Bildung, mainly between books 13 and 16 , together with a definition of the foundations of the poetic vocation that will mark the spiritual shape of Goethe's production throughout his life. To do so, it will investigate the suitability of the concept of teleology as a proper explanatory principle for the clarification of the moment mentioned above, in the light of the discussion proposed by Fotis Jannidis (1996); and it will analyze the role of the most important references and influences for Goethe in this process: Lavater, Basedow and Zimmermann among the acquaintences; Spinoza and Prometheus among the luminaries.
\end{abstract}

Keywords: Goethe; Bildung; teleology; Lavater; Spinoza.

Resumo: Concebido para suprir as lacunas de uma existência que se tornara pública e notória com a publicação do Werther, o relato autobiográfico de Dichtung und Wahrheit dedicará boa parte das quase 300 páginas de seus sete últimos livros à narração das circunstâncias que teriam possibilitado a Goethe encontrar um campo de atuação e influência compatíveis com a estrondosa repercussão do Werther, mas ao mesmo tempo condizentes com uma vocação poética a que Goethe recusa qualquer interferência direta e 'didática' nos assuntos humanos, visto como passa a concebê-la 'inteiramente como natureza'. O artigo se propõe passar em revista esse momento decisivo de elaboração da Bildung goethiana compreendido sobretudo nos livros 13 a 16, o qual coincide com a definição dos fundamentos da vocação poética que marcará a fisionomia espiritual da produção de Goethe vida afora. Para tanto, investigará a pertinência do conceito de teleologia como princípio explicativo oportuno à elucidação do referido momento, à luz da discussão proposta por Fotis Jannidis (1996); e analisará o papel das referências e influências que maior importância tiveram para Goethe nesse processo: Lavater, Basedow e Zimmermann, entre os convivas, Spinoza e Prometeu entre os luminares.

Palavras-chave: Goethe; Bildung; teleologia; Lavater; Spinoza.

1 Universidade de São Paulo, Av. Luciano Gualberto, 403, São Paulo, 05508-010, Brasil. Email: marcoantonio.climaco@gmail.com

(cc) BY-NC

Pandaemonium, São Paulo, v. 22, n. 36, jan.-abr. 2019, p. 223-256 
Audrey: Não compreendo o que seja poética. É alguma coisa conveniente em palavra e obra? Será qualquer coisa verdadeira?

Touchstone: Certamente que não, pois a mais verdadeira das poesias é a mais abundante em ficções.

(Shakespeare, Como gostais).

É possível afirmar que a partir do livro 13, a recapitulação e elaboração da Bildung que fornecem a matéria elementar à narrativa de Dichtung und Wahrheit atingem um ponto de inflexão. Com a notoriedade literária conquistada pelo Werther - pontuada de malentendidos que a mistura de ficção e realidade presente na obra dava motivos de sobra para fazer aflorar - e a urgência de uma definição quanto à sua atividade profissional e autonomia financeira, Goethe pautará desse livro em diante a legitimidade de suas concepções poéticas e a viabilidade de suas escolhas de vida, à procura de mediações e de um denominador comum, tanto estético quanto prático, entre a poesia e a verdade. Do fundo desses questionamentos e embates, veremos destacar-se a questão que, justamente neste momento histórico de liquidação dos privilégios da nobreza e disseminação da sensibilidade burguesa, se impunha de maneira candente ao artista cioso de seus dons invulgares, e que Goethe vai condensar na fórmula empregada a propósito de Klopstock no livro 15: 'fazer uso mais produtivo de seus dons excepcionais em condições restritivas'.

À sombra de um 'velho preconceito' que a intensa repercussão do Werther parecia querer ressuscitar com toda força, Goethe vai se capacitando e compenetrando cada vez mais da 'ausência de propósito didático de toda verdadeira obra de arte', propósito que o artista deve sacrificar, por um lado, no altar de um anseio de totalidade unitária que lhe cobra o preço da solidão e isolamento; e por outro, da aceitação incondicional das imperfeições particulares que incumbe justamente a ele incorporar e 'equacionar' no seio dessa totalidade. Ao mesmo tempo, no estreito convívio com personalidades eminentes que o sucesso do Werther lhe proporcionou, Goethe se daria conta da diferença fundamental entre a atuação e influência indireta com que o artista tem de contentar-se e arcar por sua consciência insubornável da 'arte como arte', e a atuação direta a que se arroga o 'idealismo moral’ com menosprezo e prejuízo da unificação artística entre o ideal de totalidade e as imperfeições particulares. 
Este artigo se propõe recapitular e sintetizar a trajetória da definição do talento poético inato de Goethe como 'fundamento de toda sua existência'², enquanto paulatino processo de solução dos impasses e dilemas do jovem autor sequioso de consolidar uma posição condizente com o raio de influência a que sua fama fora projetada pelo Werther (dilemas que este mesmo Werther se propunha justamente a dirimir, mas acabaria por escancarar), e ao mesmo tempo capturado pela certeza da inocuidade desse talento, na qualidade de dom inteiramente fundado na natureza, para o exercício de uma influência que se pretendesse direta e incisiva. Como trataremos de explicitar mais adiante, os contornos dessa trajetória se ajustam e prestam particularmente bem à ilustração e discussão do problema da teleologia em Goethe, tal como Fotis Jannidis as empreende no $4^{\circ}$ capítulo de seu minucioso e audacioso estudo a respeito do conceito de Bildung na Autobiografia do poeta alemão ${ }^{3}$.

Depois de concluir a sua narrativa das venturas e desventuras proporcionadas pelo Werther com a desaprovação do propósito didático da arte, Goethe encerrará o $13^{\circ}$ livro com um desabrido encômio ao 'magnífico' Justus Möser justamente por sua competência inigualável em 'escolher assuntos de utilidade pública' e tratá-los

[...] como um perfeito homem de negócios que (...) se dirige ao povo [...] e torna compreensíveis para cada um, de uma perspectiva correta, todas as coisas que um governo razoável e benevolente se propõe a fazer. Para tanto, não se vale, porém, de ares professorais; serve-se, antes, das mais variadas formas, que bem poderíamos chamar de poéticas, mas que também passariam por retóricas, na melhor acepção do termo (GOETHE 2017: 716).

Embora se mantenham "estritamente no âmbito do possível e do real” (id.), suas sugestões e recomendações "se provam difíceis de serem implementadas" (id.), tendo à custa disso recebido o título de Fantasias patrióticas.

É este o livro que Goethe encontrará casualmente à mesa quando do primeiro encontro que selará seu futuro, narrado umas tantas páginas adiante, com o futuro Grão Duque de Weimar, e é sob o auspício de suas virtudes que encerrará o $13^{\circ}$ livro com a profissão de fé nas esperanças de uma juventude “que também queria mostrar ao que veio

\footnotetext{
${ }^{2}$ Quando se tratar de passagens extraídas de Dichtung und Wahrheit, ipsis litteris ou levemente modificadas, as expressões citadas entre aspas simples serão outra vez objeto de citação referenciada, em passagem do artigo onde os pressupostos da sua compreensão já estejam desenvolvidos e melhor contextualizadas na discussão.

${ }^{2}$ Das Individuum und sein Jahrhundert - Eine Komponenten- und Funktionsanalyse des Begriffs 'Bildung' am Beispiel von Goethes "Dichtung und Wahrheit”. Max Niemeyer Verlag - Tübingen 1996.
} 
e que estava em vias de compreender o modo de fazê-lo" (id.) - embora não se furte a qualificar estas esperanças, no parágrafo seguinte e derradeiro do $13^{\circ}$ livro, como

[...] a nossa mais bela e doce insanidade, da qual simplesmente não podemos abrir mão, por mais que ela nos cause muita dor na vida: queremos que tudo aquilo que admiramos e veneramos nos outros possa também fazer parte de nós, pois queremos fazê-lo, criá-lo a partir de nós mesmos. (id.)

A conclusão do livro 13 dá a exata e justa medida da disposição com que Goethe adentrará uma nova etapa de sua existência, aquela em que se trata de deixar para trás o tempo das dissipações e veleidades juvenis e firmar seu nome entre os expoentes da literatura pátria, e que fizesse jus à condição de um rapaz que, depois da 'confissão geral' do Werther, "se sentia de novo alegre, livre e pronto para começar uma vida nova" (id.: 704). A expectativa de exercer sobre o seu público e seu século uma influência capaz de emular com aqueles a quem devota irrestrita veneração, entrando com eles numa relação de continuidade em que a criação artística não concebe para si distinção maior do que a de 'criar a partir de si próprio aquilo que se admira e venera nos outros'; esta expectativa, Goethe a sabe de sobejo fadada à decepção e ao olvido pela força dos ventos soprados pelos novos tempos, a que dará mais à frente o epíteto de 'desafiadores', visto como não se esperava de cada um senão "o que, até então, ninguém havia feito" (GoETHE 2017: 789 , grifo meu), confiados numa "contemplação direta da natureza em sua originalidade" (id.) e no "socorro da figura do gênio, que, com seu dom mágico, seria o único capaz de apaziguar todas as tensões e dar conta dos desafios que se impunham” (id.: 790).

Daí o caráter de flagrante e acachapante contradição, de autêntica aporia, que esta expectativa tem forçosamente de revestir aos olhos de Goethe, que não hesita reputá-la uma insanidade, muito embora doce e bela, demais de irrenunciável a despeito de toda dor que deva infligir à vida. É sob o signo desta contradição e aporia que veremos desdobrarem-se os próximos episódios da narrativa, em que Goethe, colhendo já os dividendos de sua súbita celebridade literária, desfruta com cupidez da companhia ou da ascendência direta de personalidades mais célebres e experimentadas, colhendo todavia de sua atuação e influência sempre uma nota de dissonância.

A exemplo de Justus Möser, quase todas estas personalidades não são poetas ou 'literatos'4 no sentido em que o entendemos e os designamos hoje, e é justamente esta

\footnotetext{
${ }^{4}$ A exceção é Klopstock, embora Goethe também ressalte, no retrato que nos faz dele, justamente a sua índole de 'diplomata', empenhado em prestar contas da dignidade e lutar, além de seus próprios interesses, também pelos interesses 'muito mais importantes' de um soberano e de todo um Estado, timbrando em apresentar-se "como homem valoroso e como representante de instâncias superiores, tais como a religião,

Pandaemonium, São Paulo, v. 22, n. 36, jan.-abr. 2019, p. 223-256
} 
circunstância que vai favorecer da melhor maneira o contraponto entre a sua atuação e a vocação poética de Goethe, que não obstante sequioso de fazer sua entrada e assumir sua posição no 'grande mundo', não podia deixar de considerar uma 'insanidade' toda pretensão educativa baseada na cumplicidade inequívoca entre um autor e seus modelos ${ }^{5}$ (e também seu público) - a começar pela suprema irreverência e impudência que marcaram a relação de Goethe e seu círculo de juventude para com boa parte dos autores consagrados que os precederam de perto, aos quais de resto Goethe votava sincera admiração.

\section{A 'determinação do homem' (Teleologia)}

Tratar-se-á agora de analisar a referida contradição e aporia e o papel que tiveram na determinação da vocação poética - e concomitantemente na definição da configuração da vida e do destino - de Goethe daí por diante, à luz dos conceitos de 'teleologia' e 'determinação do homem' e das reflexões que lhes dedica Jannidis. Sua tese fundamental é a de que Goethe, comumente tomado por um adversário da teleologia, emprega em verdade uma forma secularizada do modelo de pensamento teleológico, em conformidade com a qual estariam (teleologicamente) estruturados dois conceitos que lhe eram muito caros e de importância fundamental para sua Autobiografia: 'Zerstreuung' bzw. 'falsche Tendenzen' (dispersão ou 'falsas tendências') e 'Steigerung' (intensificação).

A importância e peculiaridade destes conceitos se dão melhor a conhecer quando confrontados com aquelas concepções teleológicas vigentes numa abordagem tradicional, cujo combate rendeu a Goethe a sua fama de adversário da teleologia: a 'teleologia

\footnotetext{
a moral e a liberdade", e evitando "justamente aqueles assuntos sobre os quais preferimos e até esperamos poder conversar", quais sejam, as "questões poéticas e literárias" (id.: 785). Talvez por tudo isso, Klopstock não receba tratamento tão alentado quanto aquelas personalidades que, por isso mesmo, foram tomadas para objeto deste artigo.

${ }^{5}$ Em seus anos de maturidade, Goethe atribuirá a si mesmo, sem qualquer pudor ou escrúpulos, o epíteto de 'poeta imitador' - se bem que aí seus modelos já sejam Homero, Hesíodo 'e outros' (GOETHE 1979: 412), e esta atitude já pressuponha além disso aquele processo de incubação de "certos grandiosos motivos, lendas, tradições antiquíssimas [que] se me gravaram tão profundamente na mente que os mantive vivos e operantes em meu interior durante quarenta ou cinquenta anos", de modo que "mudavam continuamente de aspecto e amadureciam até uma forma mais pura e uma mais nítida representação, embora sem transformar-se substancialmente" (id.: 1997: 212-13). Esta condição, que especifica e legitima o sentido que tem em mente ao fazer-se passar por um 'poeta imitador', Goethe a descreve para ilustrar a variante poética daquele 'pensamento objetivo' que lhe fora atribuído pelo psiquiatra J. Ch. Heinroth, dando com isso ensejo ao ensaio 'Significativo estímulo por meio de uma palavra inteligente', incluído por Goethe na sua coletânea Zur Morphologie, II,1.
}

Pandaemonium, São Paulo, v. 22, n. 36, jan.-abr. 2019, p. 223-256 
antropocêntrica', com sua 'representação físico-teológica de que tudo sobre a Terra teria sido criado apenas como meio para o homem"“ (JANNIDIS 1996: 131) e sua crença na predeterminação do curso da vida humana pela Providência; e como um desdobramento da primeira, a representação de uma 'conformidade a fins para fora' (Zweckmäßigkeit nach außen), segundo a qual os animais teriam sido primeiro criados, e então "muito engenhosamente adaptados por uma alta sabedoria ao seu respectivo elemento vital"7 (id.).

Contra esta última concepção, Goethe advoga a unidade indissociável de atuação da 'forma geral' dos seres vivos (o Tipo) e do elemento vital geral (os 'fatores determinantes' do tipo, ar, água ou terra etc.) na criação dos seres vivos: "A teoria da metamorfose de Goethe é em verdade uma tentativa de apreender o desenvolvimento de um organismo como unidade entre o tipo e as forças determinantes"8 (id.: 133). Contra a primeira, advoga que o ser humano não tem qualquer destinação ou determinação geral enquanto espécie, tal como era comum acreditar-se no século XVIII, senão que sua própria individualidade - suas faculdades particulares e suas disposições fundamentais constitui seu único objetivo de vida. Nesta divergência, aliás, vai fundar-se também o protesto de Goethe contra o uso que a botânica de seu tempo fazia dos termos 'anormal' ou 'patológico' com respeito aos desvios que o desenvolvimento individual acusa em relação ao de sua espécie - desvios nos quais Goethe não estava disposto a reconhecer senão uma tendência para a normalidade, que se alterna e complementa com a tendência do 'normal' para o 'anormal', ambos "atuando juntos e tendendo sempre um na direção do outro" (GOETHE 1997: 138).

Por aí já se vê com que espécie de problemas a formação de Goethe andava às voltas neste momento; pois se uma unificação inaudita entre as disposições e circunstâncias existenciais do indivíduo e aquelas da cultura (que aqui faz as vezes dos ‘fatores de determinação' exteriores do indivíduo humano) foi sem dúvida indispensável

\footnotetext{
6 "die physikotheologische Vorstellung, alles auf der Erde sei nur als Mittel für den Menschen geschaffen". A título de exemplo, mencione-se a presença de uma tal concepção na observação muito arguta de Stephen Dedalus sobre uma certa noção utilitária de beleza de que ele escarnece nos seguintes termos: "Por minha parte desagrada-me esta saída. Ela conduz antes à eugenia do que à estética. Conduz-te, através da confusão, para dentro duma nova e aparatosa sala de leitura onde MacCann, com uma das mãos sobre A Origem das Espécies e a outra sobre o Novo Testamento, te dirá que tu admiraste os grandes flancos da Vênus [de Praxíteles] porque sentes que ela deve dar à luz uma geração, e lhe admiravas os seus grandes seios porque sentes que ela deve dar bom leite a seus filhos e aos teus." (JOYCE 1971: 196)

7 "von einer höheren Weisheit sehr kunstvoll ihrem jeweiligen Lebenselement angepaßt worden".

8 "Goethes Metamorphoselehre ist zwar der Versuch, die Entwicklung eines Organismus als Einheit von Typus und determinierenden Kräften zu erfassen."
}

Pandaemonium, São Paulo, v. 22, n. 36, jan.-abr. 2019, p. 223-256 
para o êxito artístico e 'comercial' do Werther, não o foi menos aquele isolamento também inédito que facultou, somente ele, a intensa concentração do indivíduo em si mesmo, em suas 'faculdades particulares e disposições fundamentais' - numa palavra: em sua 'determinação teleológica' ${ }^{9}$. Extremamente bem-sucedido do ponto de vista literário no caso do Werther, o resultado desta alternância entre unificação com o mundo exterior e concentração isolada em si mesmo se tornaria ele próprio o responsável, no tocante à recepção do público, por escancarar a impossibilidade e o desatino de se pretender repetir a experiência, pondo a descoberto a heterogeneidade fundamental e constitutiva entre o autor e o público, e mais ainda, entre os 'pontos de contato exterior' e o 'tempo de nossa condição interior'. ${ }^{10}$

Para completar este quadro, Goethe tampouco se acha, não obstante a reputação recém-adquirida, à altura de se integrar plenamente a uma nova e mais consumada disposição existencial e criativa (a de 'criar a partir de si próprio aquilo que admira e venera'), disposição em que a heterogeneidade fundamental com o público e o 'contato exterior' já se tenham equacionado e dado lugar à maestria, àquela arte da distância altaneira e oniabarcante ${ }^{11}$ que Goethe vê perfeitamente consumada na figura de Justus Möser; pois a despeito de se sentir capaz de "entender e reproduzir as formas de sua [Möser] exposição", o autor do Werther ainda duvida de que jamais chegasse a "saber tanto sobre tantas coisas diferentes e ainda lidar com tanta autonomia com assuntos assim tão recalcitrantes [?]” (id.: 716).

Os dois momentos do pensamento teleológico goethiano destacados por Jannidis - a perfeita integração entre o ser humano e os fatores determinantes externos, e a

\footnotetext{
9 “[...] dado que me sentia profundamente tocado pelas semelhanças [das circunstâncias da morte de Jerusalém] em relação ao que acontecia comigo, não pude deixar de insuflar a obra em que eu vinha trabalhando com um ardor que não me permitia qualquer distinção entre o poético e o real. Isolei-me completamente do mundo exterior, refutando até mesmo as visitas de meus amigos, e consegui, também internamente, afastar-me de tudo o que não estivesse diretamente relacionado àquele propósito" (GOETHE 2017: 703).

10 “'Acontece que ele [G.] se sentia como se fora dragado [pela repercussão estrondosa do Werther] daquela condição de quietude crepuscular e obscura, a única situação propícia para a criação de obras tão genuínas; e essa mesma força o arremessou na algazarra da luz do dia, onde nos perdemos nos outros, onde somos confundidos o tempo todo tanto pela simpatia como pela frieza, pelo elogio assim como pela censura - pois que esses pontos de contato exterior não coincidem jamais com o tempo de nossa condição interior e, não sendo capazes de nos servir de estímulo, acabam necessariamente nos prejudicando" (id.: 711).

11 "Möser nos dá a impressão de estar sempre acima dos assuntos que discute, e sabe muito bem como nos oferecer uma perspectiva agradável das coisas mais sérias. Ora fala como quem se oculta parcialmente por trás de uma ou outra persona, ora assume sua própria voz. E faz isso sempre de modo abrangente, exaustivo, alegre, mais ou menos irônico, excepcionalmente competente, correto e bem-intencionado; vez ou outra é mais rude e incisivo, mas sempre de modo tão moderado que não há como deixar de admirar, a um só tempo, o espírito, a inteligência, a leveza, a habilidade, o bom gosto e o caráter desse autor" (id.: 716).
}

Pandaemonium, São Paulo, v. 22, n. 36, jan.-abr. 2019, p. 223-256 
individualidade autodeterminada por suas próprias faculdades e disposições particulares - ainda encontram-se aqui confundidos, e a despeito de sua bem-sucedida unificação (na proeza do Werther ou no ideal projetado em Möser), nem por isso deixam de ressentir-se da unilateralidade a que os predispõe sua própria natureza dual: a apoteose individual e sua identificação 'sacrificial' com a hipertrofia individualista e as "excentricidades hipocondríacas" (id.: 700) dos tempos presentes (o Werther); e a apoteose cultural e sua sofreguidão em ascender a uma sobranceira comunidade de espíritos ${ }^{12}$ de tempos já findos ou em vias de findar-se, e que à custa do seu saber universal, sua abundância de recursos e suas variadas 'personas', se coloca acima e a cavaleiro da 'recalcitrância' dos assuntos particulares (Möser).

Veremos agora como Goethe encontrou, nas relações e contatos que as circunstâncias doravante lhe oportunizaram, o ensejo para problematizar e flexibilizar o imperativo da unificação indefectível do indivíduo com os 'fatores determinantes externos' (a natureza e a cultura); e veremos como, no isolamento e aturdimento individual a que se vira lançado pela publicação do Werther, acabará por experimentar um distanciamento e ruptura com os modelos culturais vigentes que lhes serão fundamentais não apenas à intensificação e depuração das suas 'faculdades particulares e disposições fundamentais', mas também para lhe deparar os 'fatores de determinação externa' (as formas culturais) que convinham do modo mais íntimo e essencial a este mesmo isolamento e autossuficiência individuais. Dito de outro modo, neste misto de esgotamento cultural e impotência pessoal que lhe patentearam a 'insanidade', amarga ou doce, dos caminhos já trilhados (o suicídio de Werther) ou ainda por trilhar (a maestria de Möser), Goethe vai encontrar os meios de que necessitava para esquivar-se ao impasse entre indivíduo e cultura a que sua época fora dar, acenando-lhe estes meios com um acervo de imagens e recursos mais universal e individualmente satisfatório que aqueles disponibilizados pela cultura vigente, seja ela de vanguarda ou escol.

Foi somente o pleno reconhecimento dos fatores determinantes externos, revelados naquilo que tem de insofismável e iniludível pelos desdobramentos implacáveis do Werther e a inatingível maestria de Möser, que justamente permitiu a Goethe alcançar para seu próprio indivíduo aquela necessária "representação de uma predeterminação dos

\footnotetext{
${ }^{12}$ Foi Goethe, a esta altura "um estranho nem mais tão desconhecido" (id.: 714) quem, por intermédio da filha deste, encorajou Möser e "aliviou seus receios" quanto à publicação e à "utilidade e proveito muito mais geral" de sua coletânea de ensaios, inicialmente "dirigidos a um público leitor mais restrito [...]" (id., grifo meu).
} 
acontecimentos através da planta, do animal, do homem [...]", sem a qual não se pode passar "mesmo quando se reconheça os poderes atuantes no desenvolvimento dos seres orgânicos" (JANNIDIS 1996: 133) 13 $^{13}$ tal como Goethe procurou subscrever esta representação no ensaio Bildungstrieb, pleiteando para sua teoria da metamorfose uma posição intermediária entre a teoria do encapsulamento de Haller e Bonnet, fadada a 'repugnar uma pessoa de cultura superior', e a teoria epigenética com que Blumenbach teria alcançado o ápice da 'antropomorfização' do referido impulso de formação inerente aos seres orgânicos. ${ }^{14}$

Para Jannidis, justamente a correta 'apreensão do desenvolvimento de um organismo como unidade entre Tipo e poderes determinantes' visada pela teoria goethiana da metamorfose não podia prescindir do isolamento de tais poderes, com que se pudesse chegar a atinar com o 'componente teleológico dos acontecimentos':

$\mathrm{Na}$ apresentação de sua vida, mas também na reflexão teórica ele [G.] em verdade não pode evitar de, sempre de novo, isolar os fatores e com isso reconhecer um componente teleológico dos acontecimentos: Goethe fala da "Enteléquia que nada acolhe sem apropriar-se disso através de seu próprio ingrediente", mas distingue entre 'Enteléquia' e os poderes determinantes e reconhece no conceito de 'Enteléquia' o fim a que se dirigem os acontecimentos. (JANNIDIS 1996: 133) ${ }^{15}$

\section{Lavater (e Basedow)}

A primeira personalidade que viria exercer influência decisiva na determinação das convicções e da Weltanschauung goethianas neste momento crucial de sua formação será a do teólogo suíço J. Kaspar Lavater. Goethe dedica parte considerável do livro 14 ao relato de sua aproximação com Lavater e dos traços de personalidade desse homem singular, relato que retomará quase 200 páginas adiante no intuito de fazer um balanço final de sua participação no projeto da 'Fisiognomia' lavateriana.

\footnotetext{
13 "Selbst wenn man die Wirkkräfte bei der Entwicklung organischer Wesen anerkennt, kommt man doch nicht ohne eine Vorstellung von der Vorbestimmtheit des Geschehens durch die Pflanze, das Tier, den Menschen aus."

${ }^{14}$ Sobre este ponto, cf. 'Impulso de Formación' (GOETHE 1997: 187-190), especialmente a nota 16.

15 "In der Darstellung seines Lebens, aber auch in der theoretischen Reflexion kommt er allerdings immer wieder nicht umhin, die Faktoren doch zu isolieren und damit auch eine teleologische Komponente des Geschehens anzuerkennen: Goethe spricht von der "Entelechie, die nichts aufnimmt, ohne sich's durch eigene Zutat anzueignen", unterscheidet also zwischen der 'Entelechie' und den Wirkkräften und erkennt im Begriff 'Entelechie' das Zielgerichtete des Geschehens an."
}

Pandaemonium, São Paulo, v. 22, n. 36, jan.-abr. 2019, p. 223-256 
CLÍMACO, M.A.A. - A definição da vocação poética goethiana

É impossível resumir em poucas linhas as copiosíssimas informações, descrições e observações que Goethe oferece de Lavater ao longo dos livros 14 e 19; mas para os desdobramentos que pensamos dar às nossas reflexões até esse ponto, será suficiente terse em conta que tais observações se deixam, grosso modo, reportar às características da índole e caráter de Lavater que mantinham uma conexão estreita com seu empreendimento intelectual principal e um tanto obstinado, qual seja, a sua Fisiognomia.

Pouco mais velho que Goethe, também Lavater "havia sido tomado pelo espírito da liberdade e da natureza daqueles tempos [...], dizendo que, mesmo sem muitos recursos exteriores, tínhamos substância e conteúdo suficientes e que tudo dependia apenas de desenvolvermos adequadamente o que havia em nós mesmos" (GoETHE 2017: 729). Contudo, em Lavater as disposições naturais e as circunstâncias de formação se deram as mãos e concorreram para potencializar o que de melhor e pior aquela orientação geral dos tempos fomentava, suavizando por um lado o espírito de oposição com que a juventude contava levar o imperativo da liberdade às suas últimas e inexoráveis consequências, e recrudescendo por outro o caráter de necessidade natural que atribuía às suas crenças e com isso "se voltava de modo tão evidentemente contrário ao espírito secular e liberal ao qual eu [G.] aos poucos ia me convertendo [...]" (id.: 729).

Quanto às circunstâncias de formação, Goethe reconhece nelas uma das causas principais dessa comunhão, essa continuidade insensível e harmoniosa que, para o bem e para o mal, dava o tom às relações mútuas entre natureza e liberdade no credo lavateriano: "Era uma daquelas pessoas afortunadas em quem a vocação exterior e a interior coincidiam perfeitamente [...], cujas etapas de formação lograram alimentar a sua formação subsequente, de modo que seus talentos todos puderam seguir seu curso natural de desenvolvimento". (id.: 729). Já no tocante às disposições naturais, é nelas que verá radicada a contrapartida mais propriamente negativa (embora não unicamente negativa) dessa reversibilidade inequívoca entre natureza e liberdade: “[...] Lavater não nascera para a contemplação e não tinha o menor dom para a apresentação, em seu sentido estrito. Antes, sentia-se impelido a concentrar todas as suas forças no efeito de suas atividades práticas." (id.: 730).

Ambas as características, no entanto, estão intimamente ligadas e repousam ambas - como se afirmou há pouco - em seu dom ou talento fisiognômico. Com efeito, se "a unidade de sua natureza interior se fundava em um elevado senso de moralidade" (id.: 917), e se “[E]m Lavater, nele próprio, é bem possível que as ideias de um ser físico e de 
um ser moral pudessem, de fato, constituir uma unidade" (id.: 918), ele em contrapartida "não sabia como apresentar essa unidade para os outros" (id.: 917), visto como

não era capaz de conferir uma unidade exterior aos seus mais variados esforços, dado que não levava o menor jeito para o pensamento filosófico e tampouco dispunha de talentos artísticos. Não era nem pensador, nem poeta e, para sermos sinceros, nem mesmo um grande orador, no sentido estrito do termo. Incapaz de enfrentar metodicamente as questões como um todo, limitava-se à segurança com que isolava as singularidades de cada objeto e à ousadia com que as relacionava. Sua grande obra fisiognomônica é o melhor exemplo e testemunho disso. (id.: 917-18)

Exposto à companhia privada e à atuação pública de Lavater, e instado como era, ele próprio, a tomar parte direta em seu projeto fisiognômico, Goethe se aperceberá com nitidez e intensidade crescentes do vivo contraste que existe entre a natureza de Lavater e a sua própria. Em suas múltiplas facetas, tal contraste vai condensar-se e consubstanciarse numa oposição entre o 'idealismo moral' lavateriano e a modalidade de 'ideal artístico' que Goethe começa a consolidar e delinear com maior clareza exatamente neste momento e graças a este mesmo contraste, e em suas respectivas formas de predispor e pautar um modo próprio de inserção e ação no mundo. E isto de modo que a vivência deste contraste permite a Goethe lançar luz retrospectiva àquele impasse entre natureza (ou verdade) e cultura (ou poesia) que se lhe escancarara com a publicação do Werther, e ressignificá-lo à luz do entrosamento e articulação peculiares que Lavater confere aos termos deste binômio.

A coisa se apresentaria de tal modo, que aquela 'elevada unidade' entre o sensível e o moral que caracterizava Lavater terminaria por se evidenciar a Goethe como, em verdade, uma justaposição sem qualquer mediação entre realismo e idealismo, uma combinação estanque e um tanto estrambótica de duas dimensões que, não obstante coexistindo em relativa harmonia, não se comunicavam e interpenetravam realmente. Daí que se "era, na verdade, um perfeito realista, e idealismos [...] só conhecia sob a forma moral", por outro lado "sua tendência irreprimível de querer tornar real tudo o que era ideal conferiria a Lavater a fama de ser um sonhador, por mais que ele tivesse a plena convicção de que ninguém no mundo se atinha tanto à realidade quanto ele mesmo razão pela qual ele também nunca foi capaz de perceber o descompasso entre seu modo de pensar e de agir" (id.: 914-15). 
Nesta coincidência indefectível entre o real e o ideal ${ }^{16}$, Goethe reconhece não apenas a fragilidade da Fisiognomia de Lavater - de resto por ele louvada em muitas outras passagens - como também uma certa deficiência ou alienação moral, diretamente ligada à sua "condição de homem bom e generoso" (id.: 731), sua "maravilhosa sensação de humanidade" (id.) e seu "elevado senso de moralidade", e através disso à sua comichão um tanto sôfrega e pertinaz em sensibilizar ou converter o próximo ao partido de sua causa. Destarte, com a "ideia que ele alimentava dos homens e da humanidade" (id.: 728), não seria de estranhar que fosse levado a "sentir certo desprezo diante dos traços sempre particulares que fazem, de cada um, uma pessoa" (id.), das "falhas inegáveis que afastam cada indivíduo da perfeição" e que "a experiência prática insistia em contrapor a uma noção tão perfeita do humano" (id.: 731) - ao passo que os artistas, por sua parte, "não lhe pareciam nunca capazes de realizar um trabalho suficientemente preciso e verdadeiro" (id.: 728$)^{17}$.

Curiosamente, à mesma falta de disposição artística Lavater deve tanto o seu dom 'assustador' para perceber as particularidades dos seres humanos e isolar as singularidades de cada objeto - portanto o seu inveterado 'realismo' - quanto a sua incapacidade para incorporar estas particularidades, tal como realmente são, à ideia de humanidade que preside e alimenta aquele mesmo dom - e, portanto, também o seu obstinado 'idealismo'.

No que respeita às pretensões científicas da empresa, é a esta incapacidade de ir além das particularidades isoladas e articulá-las significativamente num todo que Goethe vai imputar o fracasso do projeto fisiognômico de Lavater, "mais preocupado em acumular experiências do que em lançar alguma luz sobre elas, do que em lhes dar novos ares", e destarte destinado a não passar de "uma grande coleção de linhas e traços, e também de pintas e verrugas, que ele associava a determinadas características morais e, não raro, também imorais", expondo "essa doutrina tão marcante [...] às mais obscuras

\footnotetext{
16 "Sua Fisiognomia funda-se na convicção de que a presença do mundo sensível coincide perfeitamente com a do mundo espiritual, sendo desta seu testemunho, quiçá mesmo sua representação" (id.: 914).

17 Também são dignas de nota, neste contexto, as seguintes observações de Goethe: "Lavater sentia-se imensamente incomodado na presença daquelas pessoas de aparência repulsiva, estigmatizadas irreversivelmente como inimigos declarados daquela sua doutrina do significado das formas" (id.: 733). "Lavater não simpatizava facilmente com o mundo idealizado das artes, dado que seu olhar perspicaz reconhecia muito facilmente a impossibilidade de que tais criaturas artísticas pudessem, de fato, existir como organismos vivos; diante disso, simplesmente ignorava tais composições, relegando-as ao reino das fábulas, ou mesmo ao domínio das monstruosidades" (id.: 914).
} 
interpretações, a distorções maliciosas, a piadas imbecis e a toda sorte de infâmias e ridicularizações", pelo que no entanto "esse homem excepcional não deixou de ter também sua parcela de culpa" (id.: 918). Com o "gênio fisiognomista que a natureza lhe concedera', Lavater encontrava-se, desta feita, refém destas mesmas particularidades do mundo sensível que lhe era dado penetrar e devassar mais que a nenhum outro.

Mas também no que respeita ao 'idealismo', Goethe surpreenderá nesta mesma ausência de disposição artística um aspecto decisivo e mais insuspeito. A incapacidade de incorporar ao ideal os 'traços particulares que fazem de cada um uma pessoa e o afastam da perfeição' - traços aos quais Lavater não podia reprimir certo desprezo, tingindo com isso seu idealismo de seu caráter sonhador e alienado - não passam, em última análise, de uma incapacidade em aceitar as suas próprias particularidades e fraquezas ${ }^{18}$. Tal aceitação, se por um lado é forçoso que acarrete um aprofundamento das particularidades individuais e arrisque resvalar no recrudescimento de suas idiossincrasias, Goethe não a podia por outro lado conceber sem que fosse acompanhada e dirigida por aquela disposição artística para a unidade e a articulação em um todo como aliás já fora o caso com o Werther. Nesta tendência imperativa (ou imperiosa) para a unidade, porém, o aprofundamento e isolamento individual devem encontrar a devida contrapartida e corretivo no autodistanciamento e objetivação da própria personalidade à luz da totalidade cultural e humana ${ }^{19}$, sem o que tal aprofundamento não pode redundar num autêntico conhecimento de si, nem evitar o 'descompasso entre o modo de pensar e de agir' que assinalava a conduta de Lavater.

Como veremos mais adiante, quando também Basedow tiver sido incorporado à discussão, esta hipertrofia idealista que, pela falta da mediação artística, condena as observações particulares a quedarem desmembradas e cativas do elemento sensível a despeito de toda sua penetração - essa mesma hipertrofia será causa de que um tal ideal tampouco consiga, de sua parte, conservar sua autonomia e integridade perante o sensível, devendo renunciar às suas justas prerrogativas e deixar-se, mau grado seu, arrastar e

\footnotetext{
${ }^{18}$ Nem é para menos que "A noção de humanidade que Lavater desenvolvera - e que se fundava nele mesmo e nos traços de sua própria humanidade - aproximava-se tanto da ideia de Cristo que ele trazia tão viva em si mesmo, que não lhe parecia compreensível que um ser humano pudesse viver e respirar sem ser, ao mesmo tempo, cristão" (id.: 728, grifo meu).

${ }^{19}$ A mesma (totalidade) em que Nietzsche (1955: 1025) dizia repousar o 'freudigen und vertrauenden Fatalismus' de Goethe, "que não se revolta, não se cansa e que procura formar de si mesmo uma totalidade acreditando que tudo encontra sua saúde apenas por essa totalidade e que tão somente ela faz aparecer como bons e justificados o mundo e a vida".
} 
arrebatar pelos mesmos 'propósitos terrenos' que ele deseja com tanto zelo e afã influenciar e cooptar.

Com isso podemos agora nos aproximar um pouco mais da questão do pensamento teleológico goethiano, aflorada mais acima; em Lavater, nenhum dos dois momentos contrastantes, mas complementares e indissociáveis, e por isso mesmo tão difíceis de lograr em conjunto - deste pensamento se efetuam: no lugar da 'determinação humana' (teleológica) fundada nas faculdades e disposições estritamente individuais, o idealismo moral de Lavater, ao não incorporar as particularidades que afastam cada indivíduo da perfeição, não pode escapar de corroborar ou reverberar, numa modulação própria, a concepção teleológica tradicional de uma determinação humana fundada nos atributos da espécie. Sobre isso, o progresso contínuo e imperturbado de seus talentos e disposições naturais na direção infalível de uma noção de humanidade em que se confundiam os traços de sua própria personalidade e a ideia do Cristo, não deixa de fornecer um testemunho eloquente e desconcertante.

Quanto ao outro momento - o da perfeita integração entre o ser humano e os 'fatores determinantes externos' - o problema já não será mais aqui de um déficit de individualidade, mas do seu 'reverso da moeda', qual seja, um déficit de 'universalidade'. Aqui é a ausência do processo de configuração e apresentação artística de uma totalidade coesa e articulada - que para Goethe, como ficou dito, deveria necessariamente acompanhar e presidir à aceitação das particularidades e imperfeições individuais - o que impede que em Lavater os fatores determinantes externos fossem aqueles universalmente válidos e necessários à condição humana, e nesta medida compatíveis com um ideal de ser humano concebido nos justos limites da humanidade; mas sim aqueles meramente impessoais e 'impolutos' que, especialmente neste contexto histórico particular, já não predispunham favoravelmente à aceitação dos 'desígnios superiores' humanos e de quanto neles fosse 'divino e eternal', aos quais seria preciso por isso sacrificar para se atuar com êxito sobre este contexto. No que concerne à pretensão de acomodar reciprocamente a condição humana 'universal e necessária' e os fatores determinantes externos próprios desse momento histórico - e nesse caso valendo-se de disposição artística e senso de unidade - o Werther já dera lição suficientemente persuasiva, tanto por seu desfecho ficcional quanto por seus desdobramentos factuais, de quão pouco se poderia esperar da empresa. 
Por muito admirável e cativante que fosse a personalidade de Lavater, sua peculiar conjugação de 'idealismo moralmente elevado' e aguçadíssimo senso de observação e sensibilidade para as particularidades resultava numa doutrina em que, não obstante seu notável interesse, nem o individual nem o universal genuínos podiam achar abrigo, senão que os punha conjuntamente a perder. Na convivência estreita com esse homem e na íntima participação em seu projeto fisiognômico, Goethe encontraria a ocasião de se aperceber inequivocamente de como a disposição artística para o universal e a aceitação incondicional do particular - ambas ausentes do caráter de Lavater e responsáveis pela esterilidade de sua doutrina - consistiam para ele não apenas de duas disposições essenciais e constitutivas de sua personalidade, senão de uma única e mesma disposição composta de duas facetas indissociáveis e, como tal, definidora de sua própria determinação teleológica.

O fato de que Goethe tenha podido encontrar na presença de Lavater uma 'contraimagem' em carne e osso dessa sua 'disposição primordial' responde, nesse momento de sua biografia, à necessidade de refrear a precipitação prematura das duas facetas dessa disposição, tanto em sua tendência à excessiva interioridade quanto à exterioridade demasiada. A proximidade de Lavater favorece a realização deste desígnio de ambos os lados: contrapondo uma figura admirável e sob uma série de aspectos 'exemplar' à pronunciada tendência do jovem Goethe para a autoindulgência e complacência, e ao mesmo tempo fortalecendo esta mesma tendência ao espelho e a contrapelo das tendências contrárias de Lavater e suas deficiências - e, portanto, antes pela descoberta e compenetração 'objetiva' destas últimas que pela complacência subjetiva com as primeiras.

Vem daí o reiterado escrúpulo de Goethe de fazer sempre acompanhar o reconhecimento da enorme importância e influência de Lavater, da ressalva quanto à impossibilidade dessa influência 'contribuir para a sua formação' e de se tirar dela 'proveito imediato'; nesse último caso trata-se da ação moderadora ou inibidora que essa influência exerce sobre as tendências interiores (ainda que seja pela via da exacerbação destas mesmas tendências), conforme exposto acima:

O contato com Lavater foi extremamente importante e enriquecedor para mim, especialmente porque suas provocações incessantes produziam uma verdadeira revolução em minha natureza calma e contemplativa de artista. De fato, não pude tirar daí nenhum proveito imediato, uma vez que essa agitação só fazia intensificar o quadro de dispersão que há tempos tomara conta de mim. (id.: 735) 
No primeiro caso, tratar-se-á já do fortalecimento da tendência interior em se comprazer consigo mesmo, se bem que através da percepção e encarecimento dos defeitos alheios que se contrapõem àquelas tendências e em certa medida as legitimam. Nesse momento esse contraste vai se traduzir, à vista de Goethe, na oposição entre os modos de agir e exercer influência próprios à disposição moral e à artística. E isso de tal modo que essa oposição se faz sentir muito particularmente na diferença entre a intervenção direta do agir moral e a indireta do artístico - intervenção indireta que, por sinal, também assinala a própria forma com que Goethe se apercebe agora de suas disposições primordiais ao espelho e a contrapelo daquelas de Lavater.

A diferenciação entre o 'direto' e o 'indireto' principia pela constatação de uma exigência intrínseca à arte: ela apenas exerce seu efeito legítimo com a condição de que 'seja percebida como arte'. Esse aparente truísmo tem sua razão de ser; a sua diferenciação para com a realidade é um atributo que pertence à arte por direito, excelência e definição, mas que o desenvolvimento histórico-cultural recente (de modo emblemático no Werther) terminaria por lhe sonegar. Exercer sobre o público um efeito indireto, mediado pela compreensão de suas peculiaridades e exigências intrínsecas, é uma prerrogativa da arte, mas é dever do artista doravante imprimir em sua criação os sinais que acusem a defasagem fundamental entre a arte e a realidade e assegurem a primeira de seu estatuto próprio.

Mas a referida diferenciação não para por aí, avança para uma espécie de páthos da distância, na acepção física do termo, a qual vai acrescentar ao imperativo ético/estético da 'consciência da arte como arte', a observação de uma variante prática desta mesma diferenciação, segundo a qual artista e público teriam somente que ganhar (pelo menos no que concerne à literatura, importa lembrar) com a consciência e a observância do autor como autor:

[...] observar o modo como ele [Lavater] lidava com as pessoas já era, para mim, algo bastante instrutivo, a despeito de pouco poder contribuir para minha formação. Digo isso porque minha condição era muito diferente da dele. Quem age moralmente nunca se esforça em vão, pois sementes dessa natureza costumam vingar com muito mais frequência do que modestamente nos relata a parábola do semeador do Evangelho. Já quem age como artista corre o risco de perder todo o trabalho empenhado caso sua obra não seja percebida como arte. Não é segredo, por exemplo, o quanto costumavam me inquietar meus leitores tão queridos e interessados, nem por quais razões eu me sentia tão especialmente avesso a entender-me com eles. Ali, naquela ocasião, comecei a perceber uma distância clara que me separava de Lavater, uma diferença que dizia respeito ao modo como nossos esforços repercutiam junto ao público: o dele tinha efeito em sua presença, o meu, em minha ausência. Quem com ele antipatizasse à distância, de imediato simpatizava em sua proximidade; já aqueles que, ao lerem minhas obras, tomavam-me 
por uma pessoa adorável, frustravam-se por completo ao esbarrar num ser humano tão intransigente e intratável. (id.: 734)

Eis aí um primeiro balanço (o segundo, mais circunstanciado, ficará reservado para o livro 19) da convivência e aprendizado de Goethe com Lavater, em que o 'bastante instrutivo' não o é ainda, todavia, o suficiente para 'contribuir para a formação'. Como dissemos anteriormente, a companhia de Lavater atua sobre Goethe em duas frentes, permitindo-lhe o reconhecimento - não obstante indireto, por intermédio do caráter e modo de atuação de Lavater - de suas próprias predisposições e inclinações fundamentais e a reconciliação com uma vocação artística ainda fragilizada pelas consequências recentes do Werther; mas obrigando-o ao mesmo tempo a reconhecer e depurar, ainda e sempre pelo contraexemplo de Lavater, as condições intrínsecas e indispensáveis ao melhor desempenho desta vocação artística nas circunstâncias histórico-culturais vigentes, condições que requeriam uma postura essencialmente diversa daquela que dera origem e notoriedade ao Werther. Uma relação, portanto, de continuidade e aprofundamento da própria Bildung, e ao mesmo tempo de diferenciação e alargamento dela pela incorporação em seus quadros do imperativo da 'atuação indireta'.

A esta atuação de mão dupla e ao caráter ainda germinal da orientação geral da Bildung, que neste momento apenas aflora e deve assegurar a precária e prematura coexistência de seus dois vetores opostos e complementares, todo o trecho acima citado deve o teor de mera constatação impessoal que domina cada uma de suas linhas, sem progredir ainda para um juízo de valor mais assertivo (como será o caso num trecho que abordaremos $\operatorname{logo}$ a seguir). Tal coexistência equilibrada assinala a $1^{\mathrm{a}}$ manifestação daquele par de conceitos que, teleologicamente estruturados, desmentiria a versão convencional de Goethe como mero 'adversário da teleologia', e provaria o caráter teleológico de seu conceito de Bildung: ‘dispersão ou falsas tendências' (Zerstreuung bzw. falsche Tendenzen) e 'intensificação’ (Steigerung).

Quanto à dispersão, Goethe já se tinha iniludivelmente apercebido e convencido, mau grado seu, de que à custa do sucesso do Werther e do "assédio intenso, que era ora gratificante, ora incômodo, mas que invariavelmente acabava por dispersar sua atenção" (id.: 711), jamais voltaria a desfrutar da "condição de quietude crepuscular e obscura"20

\footnotetext{
${ }^{20}$ Em bela passagem do livro 6, Goethe vai amplificar a perda de tal 'condição' ao nível do diagnóstico de um fenômeno histórico de abrangência mundial, relacionado ao retraimento do sublime pelo avanço da civilização e à sua imprescindível 'migração' e refúgio no âmbito do belo: “(...) somente aqueles sentimentos mais indefinidos e difusos, típicos da juventude e de povos incultos, são realmente propícios ao sublime; pois que, se despertado em nós por coisas externas - por coisas sem forma ou de forma 
que lhe facultaria dar cabo dos "inúmeros projetos por terminar" e do "trabalho suficiente para ocupá-lo por vários anos, mas apenas se ele [G.] fosse capaz de se dedicar a cada um deles com aquele mesmo amor e carinho" (id.). Já as falsas tendências estão radicadas em camada mais profunda, independente de circunstâncias exteriores. Sua vinculação 'siamesa' com a 'Zerstreuung' tem que ver com a constatação de que o cultivo da própria individualidade - que veio substituir "a determinação metafísica dos homens como conceito significativo" (JANNIDIS 1996: 136) ${ }^{21}$ - pressupunha, antes de mais nada, o reconhecimento inequívoco dessa individualidade.

Reportando-se ao exemplo, já um lugar comum na pesquisa goethiana, da falsa tendência de Goethe para as artes plásticas (da qual ele só viria a se convencer de uma vez por todas em sua viagem à Itália), Jannidis alude ao 'fenômeno' - reiteradamente ilustrado em Dichtung und Wahrheit - de que nada exista no indivíduo que possa impedir que ele se engane neste reconhecimento de suas disposições essenciais e que "se esforce em vão ao longo de toda a vida no cultivo de uma disposição que decididamente não lhe foi outorgada" (id.: 137) ${ }^{22}$. Em sendo assim, pergunta-se Jannidis, "[O] que mais poderia informar o jovem sobre suas disposições e com isso sobre sua determinação, senão seus desejos, que igualmente o conduzem à dispersão?” (id.) $)^{23}$.

A resposta a esta pergunta ainda depende dos acontecimentos subsequentes, que prepararão o terreno para o advento da 'Steigerung'. Já vimos como a convivência com Lavater e seu modelo levaram Goethe ao ponto de conceber uma diferença fundamental entre a atuação (ou o 'idealismo') moral e a artística - fundada numa diferenciação liminar e irrenunciável entre arte e realidade e na 'atuação indireta' do artista -, mas que por esta altura dos acontecimentos não vai além de uma mera constatação, capaz de legitimar a índole artística de Goethe apenas à força do contraexemplo de Lavater. Esta

inapreensível -, o sublime nos envolve com uma grandeza desmedida, para cuja percepção não estamos nunca preparados. [§] Quase todas as pessoas são afetadas por tais disposições de ânimo e procuram satisfazer como podem essa necessidade tão nobre. Mas do mesmo modo que o sublime é engendrado tão facilmente pelo crepúsculo e pela noite, quando as formas todas se amalgamam, ele é também rapidamente banido pelo dia, que tudo particulariza e separa. Assim, quanto maior o crescimento cultural, mais o sublime vai saindo de cena - a não ser que tenha a felicidade de buscar abrigo no belo e de se unir a ele, quando ambos alcançam, então, a condição de algo imortal, indestrutível" (id.: 270-71).

21 "[Die Ausbildung der eigenen Individualität ersetzt] die metaphysische Bestimmung des Menschen als Sinnkonzept"

22 “[Das Phänomen, daß ein Mensch] sich lebenslang vergebens um die Ausbildung einer Anlage bemüht, die ihm gar nicht gegeben ist".

23 "Was also kann den jungen Mann über seine Anlagen und damit über seine Bestimmung informieren, wenn nicht seine Wünsche, die ihn zugleich in die Zerstreuung führen?"

Pandaemonium, São Paulo, v. 22, n. 36, jan.-abr. 2019, p. 223-256 
situação vai sofrer um significativo incremento com a entrada em cena de Basedow, a quem Goethe conhecerá neste mesmo período e cuja companhia desfrutará com o mesmo interesse e cupidez, chegando mesmo a empreender uma viagem em companhia de ambos, Lavater e Basedow.

Como teórico e reformador incansável da pedagogia, Basedow conquista a simpatia e admiração de Goethe, mas a despeito de sua enorme diferença de Lavater ${ }^{24}$, as objeções que lhe faz Goethe vão incidir naquela mesma falta de senso artístico e de “caráter sensível e metódico" (id.: 739), que em Lavater se deviam ao seu pronunciado e unilateral 'realismo', enquanto em Basedow à preocupação de "respeitar as afinidades de ordem conceitual” (id.) através de desenhos que, em sua 'Obra elementar', eram "mais dispersivos do que os próprios objetos a que se referiam" (id.: grifo meu). Já no tocante ao idealismo que os distinguia a ambos, Goethe vai apontar no intuito de Basedow, de que "no futuro, a humanidade pudesse estabelecer-se nesse campo [a pedagogia] de modo mais agradável e natural” (id.: 738-39) a mesma fragilidade que já o fizera cair na conta de sua diferença com Lavater: "esse objetivo, no entanto, ele o tentaria alcançar por vias demasiadamente diretas" (id., grifo meu).

Nessa combinação de meios dispersivos e artisticamente deficitários com fins persuasivos, peremptórios e 'publicitários', Goethe poderá encontrar a senha para avançar mais um passo na direção da plena assunção de sua vocação artística e, agora sim, a uma visão mais clara das vicissitudes implicadas na atuação moral animada por ideias pouco consistentes com a realidade, embora ciosas de seu progresso. Nisso pôde Goethe se beneficiar do gênio irascível e intempestivo de Basedow, que não se preocupava, como Lavater, em dissimular seu desprezo pelas imperfeições particulares dos homens com um elevado ideal de humanidade, senão que dava plena vazão a tal desprezo, para prejuízo evidente de sua própria credibilidade e propósitos - muito embora tal desprezo tivesse menos por alvo, no seu caso, as imperfeições particulares dos indivíduos que os 'desatinos' doutrinários por eles professados, particularmente o dogma da trindade ("não se cansava de argumentar contra esse mistério tão universalmente aceito”. [id.: 740]).

Já a ação moral 'direta' não podia mais, aos olhos de Goethe, escamotear sua dívida para com a autoestima imoderada destes 'grandes homens' que, em sua flagrante desproporção com a medida humana comum, tem de ocultar os propósitos com que

24 "Seria difícil de imaginar dois tipos mais nitidamente contrastantes do que Lavater e Basedow". (id.: 738).

Pandaemonium, São Paulo, v. 22, n. 36, jan.-abr. 2019, p. 223-256 
intentam a qualquer preço impingir ao mundo aquilo que 'julgam ser divino em si mesmos', vendo-se por fim forçados a sacrificar estes propósitos e vê-los 'seguir de arrasto no curso das coisas mais efêmeras'. E já não será com aquela mesma parcimônia e certa consternação, com que reconhecera o imperativo da intervenção indireta da arte ante a presença edificante de Lavater, senão com desenfadada e altiva autoconsciência que Goethe irá agora instituir o 'modo de agir e viver sem metas nem planos' com que 'desperdiçava seu talento e seus dias ao léu' ${ }^{25}$ como medida usada para aferir a conduta destes dois senhores:

Com meu jeito extremamente livre de pensar e com meu modo de agir e de viver sem metas nem planos, não me pôde passar despercebido o fato de que Lavater e Basedow se serviam de meios intelectuais, e também espirituais, para galgarem seus objetivos mundanos. Eu, que desperdiçava meu talento e meus dias ao léu, logo percebi que esses dois homens, cada qual a seu modo, embora sempre empenhados em instruir, ensinar e influenciar os outros, também ocultavam certos propósitos que lhes eram caros e que eles insistiam em alcançar a qualquer preço. Lavater procedia com cuidado e destreza; Basedow era intenso, atrevido, por vezes torpe. E ambos pareciam tão convencidos de suas propensões, de seus projetos e da excelência de seus afazeres, que só os podíamos considerar homens da maior probidade, admirando-os e reverenciando-os. [...] Ao observar de perto esses dois homens, chegando mesmo a confidenciar-lhes minha opinião e ouvindo deles o que tinham a dizer a respeito, comecei a entender que grandes homens como aqueles costumam alimentar o desejo de difundir, mundo afora, aquilo que julgam ser divino em si mesmos. Acontece que eles logo se deparam com o mundo em sua mais pura crueza e, para conseguirem agir sobre ele, são obrigados a se equiparar a ele. Diante disso, porém, esses homens são obrigados a abrir mão de boa parte daquilo que os tornava especiais e, por fim, acabam renunciando por completo a essas qualidades excepcionais. Tudo que era divino e eternal submerge então no corpo dos propósitos mais terrenos, seguindo de arrasto no curso das coisas mais efêmeras. Foi desse ponto de vista que, àquela altura de minha vida, considerei as trajetórias daqueles dois homens, e elas me pareceram, a um só tempo, honrosas e lamentáveis; isso porque eu acreditava antever que ambos acabariam se sentindo compelidos a sacrificar seus desígnios superiores em nome dos inferiores. (id.: 756)

Diversas variáveis se associam nesta passagem para matizar e compor a imagem do homem excelente paladino de ideais morais. Para o que mais nos interessa aqui, vamos tentar resumi-la nos seguintes aspectos: a pretensão de intervir no curso dos acontecimentos e no ânimo dos homens por meios diretos, pressupõe a consciência do próprio valor e excepcionalidade e o escrúpulo de difundi-los 'mundo afora'. Para fazêlo, o homem de qualidades invulgares é obrigado a renunciar às suas prerrogativas e ajustá-las à medida humana comum - característica do homem probo. Mas tal renúncia não tem o condão de anular ou deixar ociosas - assim pensa Goethe - estas prerrogativas,

\footnotetext{
${ }^{25} \mathrm{O}$ mesmo modo que antes recebera o tratamento e epíteto de um 'quadro dispersivo', que há tempos atormentava Goethe e que o exemplo de Lavater não fazia senão intensificar.

Pandaemonium, São Paulo, v. 22, n. 36, jan.-abr. 2019, p. 223-256
} 
mas quando muito de lançá-las numa atuação clandestina, de onde seguem pondo à prova a renúncia e lhe cobrando o devido tributo - aquilo que Goethe vai assinalar com a expressão 'a qualquer preço', que faz constar da ambição 'incansável' destes homens em alcançar seus propósitos.

São estas prerrogativas por assim dizer 'recalcadas' (para nos valermos de um anacronismo) que, ao se deixarem usurpar de sua origem 'divina' e se submeter ao regime e às condições semi-conscientes da sofreguidão imperiosa do 'a qualquer preço', se tornarão suscetíveis aos 'propósitos terrenos' e presa fácil para que eles as 'levem consigo de arrasto', tornando lamentável o mesmo sacrifício das prerrogativas que, quando objeto de renúncia, fora honroso. Na caracterização que fez de Klopstock, Goethe alude a uma variante peculiar dessa dupla face da renúncia, que em Klopstock se manifestava sob a forma de extravagância:

[...] quando pessoas, a quem a natureza conferiu qualidades excepcionais, experimentam em sua vida um estreitamento excessivo de seu campo de ação - ao menos em relação aos horizontes que seu talento os teria permitido alcançar -, acabam desenvolvendo formas bastante inusitadas de comportamento; e por não saberem como se valer mais produtivamente de seus dons nessa condição restrita, fazem as coisas mais estranhas e extraordinárias para exibi-los. (786)

Como se vê, a dificuldade toda está cifrada nesta possibilidade de se fazer uso mais produtivo de dons excepcionais em condições restritivas; para Goethe, tal impasse chegara a se consubstanciar na imagem, recém citada, de uma defasagem fundamental entre o divino e o humano, que na perspectiva do idealismo moral não era possível suprir ou eludir, aos olhos de Goethe, senão pelo sacrifício dos desígnios superiores em nome dos inferiores. Se principia por ser honrosamente voluntário, este sacrifício está fadado a terminar por uma lamentável capitulação, na medida em que não dispõe de uma eficaz (ou produtiva) mediação entre as imperfeições particulares e os elevados ideais, e a atuação de uns sobre as outras se opere no registro de uma 'equiparação'.

Ao escopo da tarefa de Goethe caberia, portanto, encontrar e fazer valer o teor eminentemente produtivo e a superioridade daquelas atividades que, sem embargo, não se propõem e prestam a exercer sobre o mundo um efeito imediato nem ao seu aprimoramento moral. Do ponto de vista poético, tratava-se de legitimar a eficácia vantajosa da atuação que se vale de meios indiretos - aqueles que pressupõem a 'consciência da arte como arte' e não dissimulam seus dons excepcionais no intuito de se equiparar ao mundo que pretendem influenciar -, além de avalizar esta atuação e assegurá-la da solidão e isolamento que lhes são indispensáveis e lhes tocam em sorte, 
mas que Goethe já não tinha ilusão de que lhe seriam tão facilmente concedidos. Do ponto de vista moral, tratava-se de integrar a uma satisfatória cosmovisão, e de encontrar meios práticos para o desempenho daquele 'modo de viver sem metas nem planos e de dissipar seus talentos e dias ao léu', a fim de o viabilizar, oportunizar, otimizar e adequar às responsabilidades da vida adulta e do poeta de nomeada.

\section{Spinoza e a renúncia implacável}

Apenas para fins didáticos, apresentaremos separadamente estas duas facetas de uma mesma tarefa, embora o relato de Goethe em momento nenhum as desmembre. Em seu aspecto moral, os impulsos mais decisivos ao cumprimento desta tarefa chegaram a Goethe pelas mãos de Spinoza. Na viagem que empreendera a Köln na companhia de Lavater e Basedow, Goethe travará conhecimento com 'Fritz' Jacobi, colocando a sua nascente amizade sob o signo desse filósofo, que dez anos mais tarde tornar-se-ia o pivô de seu afastamento ${ }^{26}$. "Também ele [Jacobi] se sentia movido por uma necessidade intelectual inefável e também ele se recusava a aceitar o socorro alheio, preferindo desenvolver-se e buscar a compreensão de si por conta própria” (id.: 752). Essa independência, que vinha tão a calhar "no alvorecer de nosso desenvolvimento" (id.) a um jovem empenhado em encontrar as suas disposições essenciais (teleológicas) e um caminho próprio em meio à poderosa influência de seus modelos - mas que por isso mesmo flertava tão de perto com a irreverência e derrisão que o alavancaram à condição de celebridade literária -, esta independência iria encontrar um robusto subsídio moral e um contraponto aos seus eventuais excessos individualistas justamente em Spinoza, mais exatamente no "altruísmo ilimitado que parecia irradiar de cada uma de suas proposições" (id.: 751):

Meu pensamento foi inteiramente inundado por frases como "Quem ama a Deus de verdade, não deve exigir que Deus retribua esse amor", com todas as premissas sobre a qual ela repousa e com todas as consequências que dela decorrem. Ser altruísta em tudo e de modo ainda mais extremo no amor e na amizade, eis o que, então, traduzia o meu maior anseio, minha máxima, minha prática, de modo que o atrevimento de palavras

\footnotetext{
${ }^{26}$ À afirmação de Jacobi, de que 'só é possível crer em Deus, não conhecê-lo', Goethe reagirá numa troca de cartas com o mesmo (a 21/10/1785), com a observação de que tal convicção só convém a 'sofistas da fé'. Em seu estudo Goethe e Spinoza, Gerald Stieg (1999: 68) afirma que a expressão tinha Lavater em mira. No mesmo artigo, Stieg cita passagem de um ensaio de Dilthey a respeito do 'Estudo sobre Spinoza' de Goethe, na qual Dilthey afirma que "a demonstração de Goethe se transforma em expressão passional contra as opiniões usurpadas sobre a divindade, que tanto o haviam importunado em Lavater e Jacobi" (id., grifo meu).
}

Pandaemonium, São Paulo, v. 22, n. 36, jan.-abr. 2019, p. 223-256 
como "Se eu te amo, o que você tem a ver com isso", que eu pronunciaria bem mais tarde, provinha diretamente do meu coração. (id.: 751-52)

Não é preciso insistir no quanto este ilimitado altruísmo se presta, por si só, a fundamentar a primazia de uma atuação indireta, nos moldes daquela que Goethe reconhecera como prerrogativa da disposição artística, e que não pode esperar - ao contrário da atuação moral impelida pelo idealismo de Lavater e Basedow - colher recompensas e retribuições tão certas desta atuação, senão sob a condição de que 'sua obra seja percebida como arte'. Quando retomar com mais minúcia a influência de Spinoza no livro 16, Goethe cuidará de esclarecer os fios que ligam este aspecto moral do ilimitado altruísmo à consolidação de sua vocação poética. Na caracterização que aí faz de Spinoza e de seu "modo tão detestado e mesmo temido de compreender as coisas" (id.: 807), Goethe vai encarecer o papel central que assume a renúncia implacável na doutrina do filósofo luso-holandês.

Conquanto a vida, tanto física quanto moral, recomendem a renúncia como um imperativo assistido por razões práticas, filosóficas, religiosas e até mesmo pelo que escapa ao domínio da razão (o 'mero acaso'), é forçoso admitir que haja na consecução de um tal desiderato "algo de sobre-humano" (id.: 808), e as pessoas que se propõem a levá-la a cabo "passam a ser vistas como se fossem uma aberração, uma quimera sem o menor respeito por Deus nem pelo mundo (...)" (id.). A despeito disso, Goethe reputa tais pessoas as únicas aptas a desmentir a autoridade de sabedoria irrefutável de que goza a 'máxima falsa e blasfema', segundo a qual tudo na vida humana não passaria de vaidade $^{27}$, máxima que o homem deve unicamente à sua volubilidade, que o "torna capaz de renunciar a uma coisa a cada instante, desde que, no momento seguinte, ele sempre possa continuar buscando algo diferente" (id.: 807); e também as únicas pessoas que, "para não sucumbirem a uma forma parcial de resignação" - como aquela que Goethe já censurara a Lavater e Basedow e graças à qual "[T]udo que era divino e eternal [neles] submerge no corpo dos propósitos mais terrenos, seguindo de arrasto no curso das coisas mais efêmeras" (id.: 756) - "dispõem-se a se resignar de tudo e de uma vez por todas" (id.: 808), e "se convencem daquilo que é eterno, necessário e legítimo, procurando propor ideias que sejam implacáveis, ideias que não sejam invalidadas pelo efêmero, mas, ao contrário, confirmadas por ele" (id., grifo meu).

\footnotetext{
27 "Não valeria a pena fazer o esforço de chegar aos setenta anos, se toda a sabedoria do mundo fosse loucura perante Deus" (GOETHE 2001: 137, Aforismo 618).
}

Pandaemonium, São Paulo, v. 22, n. 36, jan.-abr. 2019, p. 223-256 
No lugar, porém, de subscrever incondicionalmente este sobre-humano princípio spinozano que submete e faz convergir toda liberdade humana ao domínio implacável da necessidade ${ }^{28}$, a filiação de Goethe à lição deste filósofo se prevalecerá de uma ligeira, mas decisiva inversão e deslocamento. Para tanto, Goethe tomará alguns parágrafos para transmitir a impressão do que existe de monstruoso e aterrador na ideia de que os animais e plantas pudessem ser dotados de arbítrio e vontade própria. Dessa impressão ele se servirá como parâmetro para 'tornar um pouco mais compreensível' o 'modo bastante peculiar de lidar com sua própria natureza' que ele desenvolveu sob o influxo “desses contrastes todos, que Spinoza destaca tão energicamente em sua obra” (id.: 811). Com este 'modo bastante peculiar' Goethe está pensando justamente na referida inversão e deslocamento.

Ao invés de tomar, como o faz Spinoza, o arbítrio e vontade humanos na conta daquilo que atenta e arremete continuamente contra o que é 'eterno, necessário e legítimo' no ser humano, devendo por isso ser submetido a renúncia implacável e arrebatado à sua irredutível volubilidade; ao invés, portanto, de considerar a vontade como aquilo que age à revelia da natureza e deve ser neutralizado pela razão (ou renúncia), Goethe vai ‘elevar’ seu inato dom poético à categoria de Natureza e deixar sob custódia dela o seu impulso criador, de tal modo que agora é a natureza quem age à revelia e 'se insurge' contra a vontade, e não mais esta contra a natureza.

Àquela altura de minha vida, eu havia chegado a um ponto em que passei a considerar meu talento para a poesia como algo perfeitamente natural, ainda mais por eu ter feito do mundo natural o objeto principal desse talento. E embora o exercício desse dom de poeta pudesse ser induzido e determinado por motivações externas, ele também se manifestava espontaneamente e, por vezes, até mesmo contra minha vontade - por sinal, era nessas ocasiões que ele se manifestava de modo mais feliz e produtivo. (id.: 811, grifo meu).

Entenda-se: a mesma (ou quase a mesma) renúncia implacável à vontade se faz necessária em ambos os casos, somente que no primeiro se trata de não deixar a vontade em nenhuma hipótese agir à revelia da natureza, e no segundo de deixar a natureza agir em qualquer circunstância - mormente naquelas em que ela se apresente com as insígnias da criação poética - à revelia da vontade. Eis aí o modo peculiar por que Goethe chegaria a dotar de um caráter de necessidade, e ao mesmo tempo revestir da produtividade

\footnotetext{
${ }^{28}$ Basta pensar na identificação audaciosa - e facilmente passível de provocar escândalo - que Spinoza opera entre a suprema virtude do ser humano e seu 'instinto de autoconservação' (se é que de instinto mesmo se trate): "Quanto mais cada um busca o que lhe é útil, isto é, quanto mais se esforça por conservar o seu ser, e é capaz disso, tanto mais é dotado de virtude; e, inversamente, à medida que cada um se descuida do que lhe é útil, isto é, à medida que se descuida de conservar o seu ser, é impotente". (SPINOZA 2011: 170)
}

Pandaemonium, São Paulo, v. 22, n. 36, jan.-abr. 2019, p. 223-256 
inerente às obras da natureza, àquele seu 'modo de viver sem metas nem planos e dissipar seu talento e dias ao léu'. Uma vez acolhido ao seio e estatuto da natureza e submetido à sua regularidade própria e necessária, tal modo de vida se veria por certo privado do estigma da dissipação e indolência, ficando em contrapartida à mercê dos caprichos da própria natureza, que "fazia brotar em mim tão espontaneamente essas obras, ora mais longas, ora mais breves", mas “também parecia adormecer de vez em quando por períodos mais alongados, de modo que, nesses intervalos, eu não me sentia capaz de produzir absolutamente nada, nem mesmo se eu o quisesse. Era então que me acometia um terrível tédio" (id.: 813-14).

Do ponto de vista prático, no que concerne à maneira de estruturar a vida mais condizente com tais concepções e suas vicissitudes, a solução que Goethe acerta em dar ao impasse nesse momento consistiu em 'pôr termo às hesitações e incertezas' e reverter em proveito próprio e alheio estes momentos em que se via abandonado pela inspiração poética, 'dedicando-se aos negócios do mundo' e permitindo assim que 'nenhuma de suas potencialidades ficasse sem uso e proveito' - e desta feita resguardando-se o direito de "pensar (...) que aquele meu adorável dom natural poderia continuar se oferecendo de modo desinteressado, quase como algo sagrado" (id.: 814).

Essa disposição não apenas parecia encontrar uma perspectiva favorável de realização naquele modo de vida que, ainda encoberto pelo véu do destino, viria em breve se concretizar pela transferência de Goethe para a corte de Weimar, como fora de fato favorecida de maneira fortuita e imprevista, pelas primeiras conversas que Goethe travou com seus futuros 'benfeitores' a propósito das Fantasias Patrióticas de Justus Möser, e que "acabaram inspirando uma impressão de minha pessoa, que talvez fosse melhor do que a que eu de fato mereceria" (id.: 774). Posto ainda não tivesse neste momento operado aquela rigorosa divisão de tarefas entre as solicitações 'dos negócios do mundo' e de seu 'adorável dom natural', Goethe não fez questão de se esquivar da falsa impressão de um escritor que conciliasse em si esta dupla demanda, reservando ao seu leitor de 40 anos mais tarde (e aos patrões de poucos meses depois) a convicção que a esta altura com certeza já pressentia, e com que arremata a passagem a seguir:

[...] eu, à luz daquele Möser, passei a impressão de preferir aqueles escritores, cujo talento provém das atividades práticas da vida e retorna imediatamente a essa esfera na forma de algo útil. A verdade, no entanto, é que trabalhos poéticos, que pairam além do mundo 
moral e sensível, só se tornam úteis por vias muito indiretas, e, ainda assim, por mero acaso $^{29}$. (id.: 774)

A conclusão de Goethe acrescenta uma nota de incerteza, quase melancólica, ao confronto entre atuação moral direta - neste caso colocada sob a égide do útil - e a atuação artística indireta, que só poderia sê-lo 'por mero acaso'. Mas é impossível deixar de observar que não foi outro senão o mero acaso quem decidiu da sorte e do futuro de Goethe junto aos 'jovens soberanos' de passagem por Frankfurt, e o fez de modo a sonegar a sua verdadeira profissão de fé neste mesmo 'mero acaso', deixando prevalecer em seu lugar a 'imerecida' imagem de Goethe como um partidário do 'útil’! Com isso somos reconduzidos à questão da determinação teleológica, e agora já em condições de incorporar a ela o elemento concludente da Steigerung, e extrair daí as derradeiras consequências buscadas por este artigo.

O duplo feitio do mero acaso nesta passagem, como opção artística que faz figura um tanto sofrível diante de um Justus Möser, mas ao mesmo tempo abre caminho, burlando e contrariando a si próprio, à sorte imerecida de cujo ponto de vista é narrada a estória $^{30}$; este duplo feitio corresponde e faz jus à Steigerung, enquanto conceito convocado a articular o talento poético elevado ao status de Natureza, e a primazia da atuação artística indireta em face do idealismo moral. Steigerung - assim sustenta Jannidis - é o ‘conceito biologicamente fundamentado' do qual Goethe se serve ao refletir sobre sua trajetória, e dar-se conta de que "[O] desenvolvimento transcorre na direção de

\footnotetext{
${ }^{29}$ Sobre esta relação indireta e 'tortuosa' entre o 'belo' e o 'útil', Goethe afirmará em sua 'Resenha sobre A imitação formadora do belo de Moritz': "O nobre e o bom estão, por assim dizer, no centro entre o belo e o útil; o bom e o nobre se elevam até o belo. O útil pode unir-se com o ruim, o ruim com o inútil; e onde parecem se afastar ao máximo, os conceitos novamente se encontram, por assim dizer, num círculo. Tratase de uma prerrogativa do belo não precisar ser útil” (GOETHE 2005: 58).

${ }^{30}$ Foi nesse mesmo diapasão que Goethe pôde alcunhar (em conversa com Chanceler von Müller) seu herói Wilhelm Meister de 'pobre diabo', reservando para o desfecho e consagração de seus anos de aprendizado a 'felicidade imerecida' (o casamento com Natalie) que ele "não trocaria por nada no mundo" (GOETHE 2009: 575). Aliás, Goethe apontou em mais de uma ocasião este final como chave para o entendimento da obra, a exemplo da conversa com Eckermann do dia 18/01/1825: "Essa, aliás, é uma daquelas obras incomensuráveis, cuja chave eu mesmo não possuo. Procuram nela um núcleo, isso é difícil e não é nem mesmo bom. Eu devia ter pensado que uma vida rica e multifacetada que se desenrola diante de nossos olhos já teria em si um significado, mesmo carecendo de uma tendência declarada, que afinal existe apenas para fins de conceituação. Mas caso se deseje absolutamente algo desse gênero, que se tenham presentes as palavras que Friedrich dirige ao nosso herói no final do romance: "Você me faz pensar em Saul, filho de Kis, que saiu em busca das mulas de seu pai e encontrou um reino". Atenham-se a isso. Pois no fundo a obra em conjunto parece querer dizer tão somente que, apesar de todas as sandices e confusões, o homem, guiado por mão superior, chega a uma conclusão feliz" (ECKERMANN 2017: 146).
}

Pandaemonium, São Paulo, v. 22, n. 36, jan.-abr. 2019, p. 223-256 
um melhor, metaforicamente dito, "para cima",31, e de que "[A] transformação dos homens através da 'Bildung' segue certas regularidades"32 (JANNIDIS 1996: 139).

Que esta 'regularidade para cima' não implique, a despeito de partilhar da necessidade da própria natureza, numa evolução inexorável e 'fatalista' do gênero humano, mas bem ao contrário, que se coadune com a incerteza da atuação artística indireta e a solidão e isolamento exigidos por esta atuação e exacerbados pelo 'modo tão detestado e temido de compreender as coisas' herdado de Spinoza: esta é uma confusão que teria levado parte da crítica a pretender que Goethe não aplicasse o conceito de Steigerung ao domínio humano, mas somente ao da natureza. A isto Jannidis responde tratar-se de uma falsa oposição, à qual Goethe sobrepõe a diferenciação entre indivíduo e espécie; não é o indivíduo que é acolhido pela natureza em sua evolução genérica, mas sim a natureza que, assim como o homem particular, só enquanto indivíduo - por exemplo nas plantas isoladas que Goethe toma para objeto em sua Metamorfose das plantas - pode dar testemunho do fenômeno da Steigerung. "Em um desenvolvimento da natureza ou da humanidade como um todo Goethe via de regra não podia acreditar. A Bildung dos indivíduos, ao contrário, sem dúvida obedecia justamente a este princípio da Steigerung" ${ }^{33}$ (id.: 139).

A própria maneira indireta de admitir, como que de contrabando, o vetor teleológico da intervenção do 'mero acaso' (e da atuação indireta a ele ligada) - o mesmo que o trecho citado parece deplorar -, explicita o procedimento goethiano de coadunar o ponto de vista da natureza e do acaso com que ela rege a vida humana, com a perspectiva teleológica que abarca a totalidade desta vida e subjaz à visada natural como um pontode-fuga e um desígnio superior - ilustrando à perfeição a observação de Jannidis de que o conceito de Steigerung determina a apresentação em Dichtung und Wahrheit não apenas ao nível do conteúdo, senão também ao nível formal:

O conceito goethiano de Steigerung, que é um componente importante do conceito de Bildung, determina a apresentação em Dichtung und Wahrheit não apenas ao nível do conteúdo, mas acima de tudo ao nível formal. A perspectiva e atitude narrativas obedecem igualmente a este conceito. Reiteradamente se sinaliza ao leitor a distância do autor Goethe para com sua figura Goethe. Esta distância não consiste em uma depreciação da conduta do jovem Goethe, senão que o narrador vê-se a si próprio de um ponto de vista superior, a partir do qual ele abrange sua conduta com a vista. A conduta do jovem Goethe

\footnotetext{
31 "Die Entwicklung verläuft zum Besseren, bildlich gesprochen nach 'oben' [...]”.

32 “Die Veränderung des Menschen durch die 'Bildung' folgt gewissen Gesetzmäßigkeiten.”

33 “An eine Entwicklung der ganzen Natur bzw. der Menschheit konnte Goethe meistens nicht glauben. Die Bildung des Individuums dagegen gehorchte ohne Zweifel eben diesem Prinzip der Steigerung”.
}

Pandaemonium, São Paulo, v. 22, n. 36, jan.-abr. 2019, p. 223-256 
- isso é repetidamente sugerido - é inteiramente apropriada ao seu estágio de desenvolvimento; é certo que também se sinaliza ao leitor que as convicções, que presidem esta conduta distam mais da verdade, ao passo que o ponto de vista do narrador está mais próximo de uma verdade em última análise existente. (id.: 139-40) ${ }^{34}$

A estratégia formal, por meio da qual o mero acaso (o 'estágio de desenvolvimento apropriado ao jovem') e o componente teleológico (a 'verdade em última análise existente') se conciliam, pressupõe naturalmente que se tenha galgado o ponto de vista privilegiado a partir do qual os estágios de desenvolvimento pregressos recebem o seu aval e o selo de 'apropriados' - aquele ponto a partir do qual também se elabora o relato autobiográfico. Resta-nos ainda, no entanto, apresentar a direção e conformação que Goethe imprimiria à sua inventiva poética no próprio estágio de desenvolvimento a ser futuramente endossado, como parte fundamental da resolução da contradição inerente ao pensamento teleológico e condição indispensável para que alcançasse aquele ponto de vista do qual nos fez chegar seu relato.

No que concerne à solução teórica e à cosmovisão que a sustenta, a exigência moral de aceitação incondicional das imperfeições particulares e o anseio poético à totalidade unitária - cujas ausências desmascararam e desautorizaram, aos olhos de Goethe, o idealismo moral de Lavater e Basedow - já haviam entrado em bons termos e selaram seu acordo graças à apropriação da renúncia spinozana e sua aplicação, ligeiramente deslocada, ao talento poético entendido inteiramente como natureza. Mas esta solução não poderia estar completa, se Goethe não chegasse a dar expressão poética concreta - e apenas assim produtiva como o é a própria natureza - a esta renúncia, diferenciando-a com isso da renúncia involuntária e 'lamentável' com que Lavater e Basedow se viam constrangidos a ocultar seus propósitos e abrir mão de suas qualidades excepcionais a fim de equiparar-se ao mundo e influenciá-lo a qualquer preço, terminando às custas disso por submergir "no corpo dos propósitos mais terrenos, [e] seguindo de arrasto no curso das coisas mais efêmeras" (GoETHE 2017: 756).

\footnotetext{
34 "Goethes Konzept der Steigerung, das eine wichtige Komponente des Bildungskonzepts ist, bestimmt die Darstellung in Dichtung und Wahrheit nicht nur inhaltlich, sondern vor allem auch formal. Die Erzählperspektive und -haltung gehorcht ebenfalls diesem Konzept. Immer wieder wird dem Leser die Distanz des Autors Goethe zu seiner Figur Goethe signalisiert. Diese Distanz besteht nicht in einer Abwertung der Handlungen des jungen Goethe, sondern der Erzähler sieht sich selbst auf einem überlegenen Standpunkt, von dem aus er das Verhalten seiner Figur überblickt. Das Verhalten des jungen Goethe ist seinem Stand der Entwicklung, so wird wiederholt suggeriert, durchaus angemessen; allerdings wird dem Leser auch signalisiert, daß die Überzeugungen, die dieses Verhalten leiten, wahrheitsferner sind, der Standpunkt des Erzählers aber näher an einer letztendlich vorhandenen Wahrheit liegt.”
} 


\section{Prometeu (e Zimmermann)}

Nesta expressão poética concreta, a responsabilidade dos homens dotados de qualidades excepcionais, em lugar de impelir à transformação do mundo segundo seus propósitos 'mundanos', antes pesam sobre o indivíduo sob a forma do sentimento de nada poder esperar dos homens (como esperava Basedow) ou mesmo da divindade (como esperava Lavater) para a consecução das tarefas mais graves e decisivas, que embora sendo "destino comum da humanidade, cujo peso todos nós estamos fadados a carregar, deve pesar ainda mais sobre aquelas pessoas em quem as aptidões intelectuais se desenvolvem mais ampla e precocemente" (id.: 766). Mas justamente por ter de renunciar ao auxílio dos homens e deuses para aquilo que se sente instado e apto a realizar, pode o indivíduo diferenciar-se radicalmente de uns e de outros, reconhecendo-se como individualidade isolada e independente deles em suas disposições e aptidões, e a um só tempo submetido e unido a eles em seus propósitos e desígnios, enquanto 'destino comum da humanidade' que ele sabe ter de suportar, permitindo-se para tanto servir-se, em contrapartida, de seus próprios meios e recursos e desdenhar aqueles de ordinário admitidos e recomendados para aliviar-se dessa carga ${ }^{35}$.

Esta é a forma em que se coadunam em Goethe os dois momentos do pensamento teleológico assinalados por Jannidis - a perfeita integração entre o ser humano e os fatores determinantes externos, e a individualidade autodeterminada por suas próprias faculdades e disposições particulares. No plano poético, Goethe iria encontrar para esta atividade que desdenha o auxílio de homens e deuses para carregar sozinho com o fardo da vida humana, mas ao mesmo tempo se recusa a imputar-lhes responsabilidade direta por este fardo - seja já no intuito de influenciá-los, seja já de contestar-lhes a autoridade - uma imagem sob medida na figura mitológica do titã Prometeu. O caráter sobre-humano desta renúncia não apenas ao auxílio de deuses e homens, mas sobretudo aos próprios ideais que elevam os homens acima de seus semelhantes e lhes conferem algo de divino, mas também colocam tais ideais sob a custódia destes semelhantes e os deixam à sua mercê a este caráter a imagem de Prometeu parecera agora servir a Goethe à perfeição.

\footnotetext{
${ }^{35}$ Aqui vem muito a propósito as palavras empregadas por Fausto para rechaçar as ofertas com que Mefisto acredita poder recompensá-lo pela aposta, e para fazer saber a Mefisto as verdadeiras motivações que o levaram a firmá-la: "Meu peito, da ânsia de saber curado, / A dor nenhuma fugirá do mundo, / E o que a toda a humanidade é doado, / Quero gozar no próprio Eu, a fundo, / Com a alma the colher o vil e o mais perfeito, / Juntar-lhe a dor e o bem-estar no peito, / E, destarte, ao seu Ser ampliar meu próprio Ser, / E, com ela, afinal, também eu perecer". (GOETHE 2004: 175, vv. 1.765-75)
}

Pandaemonium, São Paulo, v. 22, n. 36, jan.-abr. 2019, p. 223-256 
Não é absolutamente um acaso que para legitimar esta 'independência' que lhe punha à margem e em maus termos com os assuntos divinos e humanos, Goethe tenha encontrado ponto de apoio e salvaguarda justamente em seu "talento para a criação poética", que lhe assistia e brindava à revelia de qualquer ideal moral, e mesmo de sua vontade, assaltando-o e 'ganhando corpo' por isso mesmo de preferência "à noite, até mesmo em meus sonhos, [...] ou na alta madrugada [...]" (id.: 767). A coincidência entre independência que desdenha o auxílio de homens e deuses, e dom poético natural que tampouco cuida de tomá-los como objeto de seu zelo ou hostilidade, encontrará perfeita correspondência nessa figura semi-divina, semi-humana, cuja rebeldia contra as 'entidades superiores' está a serviço do impulso de criar e dar forma, e não de "destruir a criação maravilhosa de uma entidade superior", como o diabo do monoteísmo que, tal como o Deus único a quem se opõe, “não são figuras poéticas” (id.: 769).

Não bastasse a independência e isolamento com que tem de arcar por seu impulso criador indiferente a ideais morais, também aquela atuação indireta que Goethe contrapunha a tais ideais e reconhecia como apanágio da poesia, tampouco deixa de estar contemplada no mito de Prometeu, cujo "lugar legítimo é, sem sombra de dúvida, a poesia" (id.), e que por isso mesmo o recomendava muito especialmente à figuração do ato de criação poética:

Além do mais, é especialmente bela e tem tudo a ver com poesia a ideia de atribuir a criação dos homens não ao ordenador supremo do universo, mas, sim, a uma figura intermediária, que, no entanto, por descender da mais ancestral das dinastias, é suficientemente digno e valoroso para fazê-lo. (id.: 769)

Sob o auspício desta 'figura intermediária', Goethe pode proceder agora à rigorosa delimitação entre força criativa / disposição de um lado, e execução de obras artísticas de outro. Se nos tempos há bem pouco passados do Werther, solidão e isolamento se afiguravam um sintoma inexorável e devastador do choque entre indivíduos excepcionalmente dotados e condições restritivas da vida burguesa, incidindo diretamente sobre a 'força criativa' e a 'disposição' e convertendo-se numa enfermidade existencial por excelência; já agora este choque pode deixar intactas a força criativa e a disposição, circunscrevendo solidão e isolamento estritamente ao nível da execução - e portanto a um problema que toca ao indivíduo que já aprendera a renunciar às pretensões divinas da alçada do 'ordenador supremo do universo' e não mais precisa cuidar de ocultar às suas próprias, mas que tampouco admite acolher nada que pudesse provir dessa esfera divina entre os recursos e expedientes 'intermediários' que subsidiam sua atividade criadora, 
como o fez "Prometeu, que, apartado dos deuses, fora capaz de povoar um mundo todo a partir de sua oficina" (id.: 767):

Eu sabia muito bem que, para produzir algo de significativo, era necessário isolamento. As obras que eu escrevera e que foram bem recebidas pelo público eram todas filhas da solidão. Desde que eu passara a manter relações mais amplas com o mundo, nunca me faltaram nem força criativa nem disposição; mas eu estacava sempre no momento da execução das obras, pois não tinha um estilo próprio nem em prosa nem em verso, o que significava que, a cada novo trabalho, eu era obrigado a começar tudo de novo do zero, aos tateios. E como, para tanto, eu descartara e mesmo rejeitara o amparo de todo mundo, acabei me isolando também dos deuses, assim como Prometeu. (id.: 767-68)

A enorme importância dessa distinção poderá ser melhor aquilatada por ocasião do relato que Goethe fará algumas páginas adiante da última personalidade dentre aquelas de maior envergadura com as quais privou e que exerceram sobre ele grande influência neste período, a qual faria jus a apreciação mais circunstanciada, só comparável em extensão àquela dedicada a Lavater: o médico (também suíço) Zimmermann. Não por acaso a aproximação com este homem 20 anos mais velho se dá sob o signo da altivez e autocontentamento (que Goethe faz questão de distinguir da satisfação oca com a própria inanidade e vazio, só esta suscetível à pecha de 'vaidade'), os quais sabia relevar a Zimmermann, que os tinha muito pronunciados, visto como também a seu próprio respeito, Goethe admite que "nunca me deixei incomodar por aquilo que as pessoas consideravam ser pura vaidade" (id.: 787) e "sem qualquer comedimento, chamava a atenção dos outros para aquelas coisas de que eu gostava em mim mesmo" (id.).

Já a diferença entre ambos, que se tornará particularmente instrutiva para Goethe, estava em que este já se capacitara, com Prometeu, de que era preciso restringir toda satisfação consentida aos dons naturais, à compensação e ao contentamento velado que o seu simples exercício pode proporcionar, não esperando nada deles ali onde se arrogam a prerrogativa divina de não apenas 'criar e dar forma', mas também de desbaratar a estultice humana e edificar em seu lugar um mundo à sua imagem e semelhança, contando colher disso a aprovação e o aplauso que os homens nunca concedem com suficiente liberalidade. O ofício de médico projetava Zimmermann na vanguarda das reivindicações e esperanças que nestes tempos se entretinha com verdadeira paixão, e que muito favoreciam a entronização daquelas prerrogativas divinas como medida dos anseios humanos: a ideia de que fosse possível, além de imperativa e nem tão difícil assim, a contemplação direta da natureza em sua originalidade - "como se a víssemos e a considerássemos pela primeira vez na vida" (id.: 790) -, enquanto "melhor base de 
fundamentação das práticas humanas' e único meio para 'dar lugar ao que é certo e verdadeiro'.

No relato da figura de Zimmermann, Goethe deixa sutilmente entretecerem-se e confluírem estas duas facetas, aparentemente contraditórias, do 'idealismo moral', que por um lado se arroga uma atuação e transformação direta do ser humano, fazendo para tanto pouco caso da natureza ou dos 'desígnios inferiores' e findando por capitular a eles; e que por outro se arroga uma contemplação e compreensão diretas da natureza, fazendo para tanto pouco caso da cultura e findando por ter de depositar todas as suas esperanças no socorro do gênio e seus 'dons mágicos'. Ao honroso imperativo da 'experiência', que o médico Zimmermann ostentava e brandia com fervor ímpar, vemos a pouco e pouco se sobrepor e confundir a imagem das 'coisas mais efêmeras' que levam consigo de arrasto tudo quanto se pretenda eternal e divino e lhe faz desempenhar lamentável figura, a qual no caso de Zimmermann chegava mesmo às raias da infâmia e da loucura, a despeito de seus grandes méritos.

Sem ser, em absoluto, insensível ao apelo e encantos da natureza, as consequências do Werther, a influência de Spinoza e a companhia de Lavater, Basedow e Zimmermann - e mais quantos outros sucessos pudemos apresentar ou tivemos que omitir neste texto - já tinham podido convencer Goethe de que "não somos capazes de enxergar as coisas como os gregos e que nunca faremos versos, nem esculturas, nem curas como eles" (id.: 790), e de que "já havíamos experimentado coisas demais por nossa própria conta, e nem sempre da maneira mais pura, de modo que nossas experiências acabaram se constituindo, mais frequentemente, a partir de opiniões" (id.). Neste campo, toda contemplação e compreensão direta e imediata da natureza teriam que evoluir e culminar na incorporação, nelas, da cultura sob a forma da observação ativa e irrenunciável do indivíduo historicamente constituído e da construção de um corpus experimental historicamente compartilhado, culminando na 'simbólica'36, na 'delicada empiria'37 e nos 'experimentos de nível superior' ${ }^{38}$ que caracterizariam a peculiar interação entre experiência e conhecimento na Morfologia goethiana.

\footnotetext{
${ }^{36}$ A respeito da simbólica, Gerald Stieg chega a afirmar que "a ideia mesma do 'símbolo' goethiano é a consequência de seu spinozismo. Pois o 'símbolo', tal como Goethe o entende, não é possível senão no interior de uma visão spinozista da natureza" (1999: 75). ("l'idée même du 'symbole' goethéen est la conséquence de son spinozisme. Car le 'symbole' tel que Goethe l'entend n'est possible qu'à l'intérieur d'une vision spinoziste de la nature").

${ }^{37}$ Em 'Maximen und Reflexionen' (Aforismo 565), (GoETHE 2003: 114).

${ }^{38} \mathrm{Em}$ 'El experimento como mediador entre sujeto y objeto' (GOETHE 1997: 151-165).

Pandaemonium, São Paulo, v. 22, n. 36, jan.-abr. 2019, p. 223-256
} 
Quanto à atuação direta dos homens excepcionais na reversão dos desatinos do seu tempo, Goethe também já se havia a esta altura convencido de que "na verdade, o absurdo repletava o mundo" (GoETHE 2017: 791) e que "é natural que os desacertos, afastados pela trajetória marcante de espíritos brilhantes, voltem a tomar conta de tudo logo após sua passagem por nós" (id.). Neste campo, são já a cultura e os "propósitos mundanos' que tem de refluir e amalgamar-se à natureza - àquela Steigerung das aptidões naturais que Goethe reputava, segundo Jannidis, apanágio dos indivíduos e não da humanidade e da natureza como um todo. À condição dessa compenetração recíproca e dessa 'reversibilidade' entre cultura e natureza, pode Goethe abandonar-se confiadamente à ideia de uma destinação teleológica inerente ao cultivo de sua natureza individual, já agora um patrimônio a salvo de ser arrastado pelo destino comum da espécie, e de confundir-se com o tributo que a autonomia individual tampouco pode se eximir de pagar a este destino (como confessa Goethe nesta passagem, com que põe fim ao relato de sua convivência com Zimmermann, e nós a este artigo):

Assim, também seus [de Zimmermann] discursos de médico, tanto quanto o dos filósofos e de meus amigos poetas, remetiam-me sempre de volta à natureza. De seu apaixonado furor reformador eu não conseguia compartilhar completamente; tanto que, depois de nos despedirmos, voltei de imediato a mergulhar no campo que me era mais próprio, tratando de me empenhar regularmente para fazer melhor uso dos talentos que a natureza me havia concedido. E em meio à batalha intensa contra tudo o que eu reprovava, procurei reservar um pouco de espaço para mim mesmo, sem me preocupar tanto com os efeitos das coisas que eu fazia, nem com o destino para o qual elas acabariam me encaminhando. (id.: 79192)

\section{Referências bibliográficas}

ECKERMANN, Johann Peter. Conversações com Goethe nos últimos anos de sua vida: 1823-1832. Tradução de Mario Luiz Frungillo. São Paulo: Editora Unesp Digital, 2017.

GoETHE, Johann Wolfgang von. De minha vida - Poesia e Verdade. Tradução, apresentação e notas de Mauricio Mendonça Cardozo. São Paulo: Editora Unesp, 2017.

. Escritos sobre arte. Introdução, tradução e notas de Marco Aurélio Werle. São Paulo: Associação Editorial Humanitas; Imprensa Oficial do Estado de São Paulo, 2005.

. Fausto: Uma tragédia (primeira parte). Tradução de Jenny Klabin Segall; Apresentação, comentários e notas de Marcus Vinicius Mazzari; Ilustrações de Eugène Delacroix. São Paulo: Editora 34, 2004.

. Máximas e Reflexões. Introdução e notas de Afonso Teixeira da Mota. Lisboa: Guimarães Editores, 2001.

. Maximen und Reflexionen. Frankfurt am Main/Leipzig: Insel Verlag, 2003.

. Os anos de aprendizado de Wilhelm Meister. Tradução de Nicolino Simone Neto; Posfácio de Georg Lukács; Apresentação de Marcus Vinicius Mazzari. São Paulo: Editora 34, 2009.

Pandaemonium, São Paulo, v. 22, n. 36, jan.-abr. 2019, p. 223-256 
CLÍMACO, M.A.A. - A definição da vocação poética goethiana

Poemas; antologia, versão portuguesa, notas e comentários de Paulo Quintela. Coimbra: Acta Universitatis Conimbrigensis, 1979.

. Teoría de la Naturaleza. Estudio preliminar, traducción y notas de Diego Sánchez Meca. Madrid: Editorial Tecnos, 1997.

JANNIDIS, Fotis. Das Individuum und sein Jahrhundert - Eine Komponenten- und Funktionsanalyse des Begriffs 'Bildung' am Beispiel von Goethes 'Dichtung und Wahrheit”. Tübingen: Max Niemeyer Verlag, 1996.

JOYCE, James. Retrato do artista quando jovem. Os imortais da literatura universal 15. Tradução de José Geraldo Vieira. Rio de Janeiro: Editora Abril Cultural, 1971.

NIETZSCHE, Friedrich. Götzen-Dämmerung, oder: Wie man mit dem Hammer philosophiert. München: Carl Hanser Verlag, 1955.

SHAKeSPEARE, William. Como gostais. Nova versão, anotada, de F. Carlos de Almeida Cunha Medeiros e Oscar Mendes. Obra Completa Volume II. Rio de Janeiro: Companhia José Aguilar Editora, 1969.

SPINOZA, Benedictus de. Ética. Tradução de Tomaz Tadeu. Belo Horizonte: Autêntica, 2011.

STIEG, Gerald. Goethe et Spinoza. Revue germanique internationale, n. 12, 1999, p. 63-75.

Recebido em 12 de junho de 2018

Aceito em 13 de agosto de 2018

Pandaemonium, São Paulo, v. 22, n. 36, jan.-abr. 2019, p. 223-256 